\title{
Fire design of arch-type timber roof
}

\section{Проектирование огнестойких арочных деревянных покрытий}

\author{
T. Saknite, \\ D. Serdjuks, \\ V. Goremikins, \\ L. Pakrastins, \\ Riga Technical University, Riga, Latvia \\ N.I. Vatin, \\ Peter the Great St. Petersburg Polytechnic \\ University, St. Petersburg, Russia
}

Key words: punched steel plates; response surface method; fire resistance

\author{
Студент T. Сакните, \\ д-р техн. наук, профессор Д.О. Сердюк, \\ д-р техн. наук, ведущий научный сотрудник \\ В.В. Горемыкин, \\ д-р техн. наук, руководитель кафедры \\ Л. Пакрастиньш, \\ Рижский технический университет, Рига, \\ Латвия \\ д-р техн. наук, директор Инженерно- \\ строительного института Н.И. Ватин, \\ Санкт-Петербургский политехнический \\ университет Петра Великого, Санкт- \\ Петербург, Россия
}

Ключевые слова: перфорированные стальные пластины; метод поверхности отклика; огнестойкость

\begin{abstract}
Lattice timber structures, which are made of elements connected by punched steel plates, are widely used for residential and industrial buildings. The main types of the structures are trusses, frames, and arches, which enables covering spans up to $30 \mathrm{~m}$ and more. The behavior of structures on fire plays an important role in the design process of the structures. The cylindrical roof with a $30 \mathrm{~m}$ span and the main load-bearing structures of lattice arches with elements connected by punched metal plates was considered as an object of investigation. The rational geometrical parameters of a lattice timber arch with punched steel plated joints were evaluated. Fire resistance and a possibility to increase it for an arch-type timber roof was also considered. It was obtained that using a protective layer is a preferable method of a fire resistance increase for the lattice timber arch due to arch joints; the material consumption was also increased by 1.65 times. It was shown that the rational values of the height of the arch, depth of the arch cross-section, and distance between the nodes on the top chord are equal to $7.85,1.10$, and $0.95 \mathrm{~m}$ respectively.
\end{abstract}

Аннотация. Решетчатые деревянные конструкции с узлами, выполненными с применением зубчатых стальных пластин, широко используются В промышленном и гражданском строительстве. Фермы, рамы и арки являются основными типами данных конструкций позволяющих перекрывать пролеты до 30 м и более. Оценка огнестойкости конструкций имеет большое значение при проектировании. Цилиндрическое покрытие пролетом 30 м с главными несущими элементами в виде решетчатых деревянных арок с узлами, выполненными с применением зубчатых стальных пластин, рассмотрено в качестве объекта исследования. Рациональные с точки зрения расхода конструктивных материалов геометрические параметры цилиндрического покрытия определены при помощи численного эксперимента. При этом произведена оценка огнестойкости основных конструктивных элементов, а так же возможности ее повышения. Показано, что наиболее эфрфективным способом повышения огнестойкости решетчатых деревянных арок является использование защитных покрытий. Расход конструктивных материалов при этом возрастает в 1.65 раз. Показано, что рациональные с точки зрения расхода материалов величины высоты арки, высоты сечения арки и длинны панели верхнего пояса равны 7.85, 1.10 и $0.95 \mathrm{~m}$, соответственно.

\section{Introduction}

Lattice timber structures can be divided into the groups depending on the types of fasteners which are used for joints. Nails, split rings, tooth steel plates, and punched steel plates are the main types of fasteners, which are used for joints of the lattice timber structures. The lattice timber structures, which are made of elements connected by punched steel plates (Fig. 1), are widely used for residential and 
industrial buildings in Latvia and abroad. The main types of the structures are trusses, frames, and arches, which enables covering the spans up to $30 \mathrm{~m}$ and more $[1,2]$.

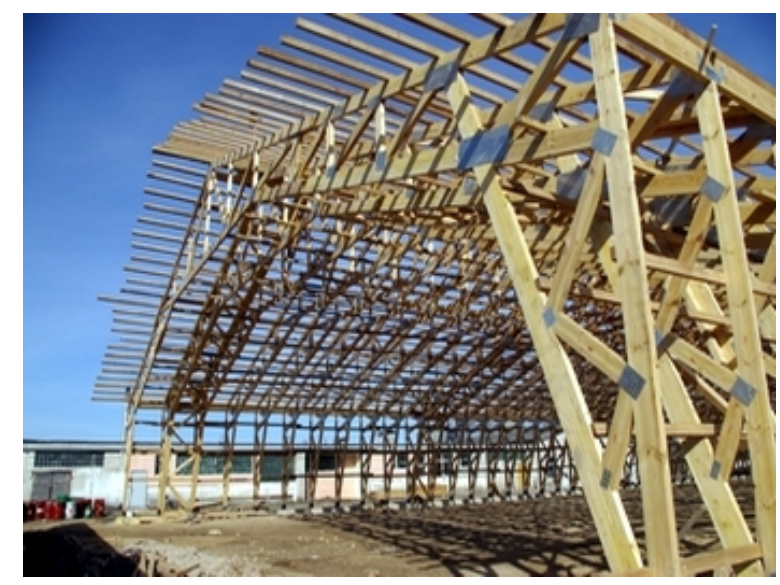

Figure 1. Lattice frame with elements connected by punched steel plates

The lattice timber arches, which are made of elements connected by punched steel plates (Fig. 2), cause an increased interest due to relatively low consumption of materials in comparison with similar lattice timber structures due to rational distribution of internal forces.

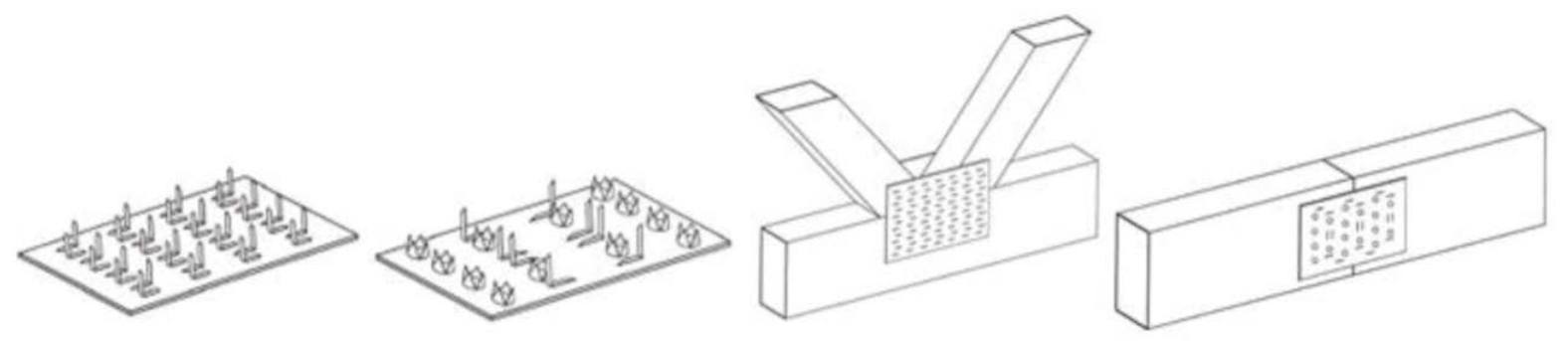

Figure 2. Joints of the lattice timber structures, which are made of elements connected by punched steel plates

Moreover, the decreased dead weight of one unit simplifies the assembling process. However, the lattice timber structures possess a number of disadvantages: increased number of assembling units, decreased fire resistance, and decreased span. All these disadvantages are derivative from the limited dimensions of the member's cross-sections. Therefore, the width of the chords and elements of the lattice is limited to $60 \mathrm{~mm}$. It can be increased up to $70 \mathrm{~mm}$ in outstanding cases. The choice of rational geometrical parameters enables decreasing consumption of structural materials and increasing effectiveness of the structure.

The behaviour of structures on fire plays an important role in the design process of structures [3]. Since the 1990s, many research projects have been focused on the fire behavior of timber structures worldwide, in particular, light timber frame constructions $[4,5]$.

The cylindrical roof with the main load-bearing structures of lattice arches with the elements connected by punched metal plates was considered as an object of investigation. The step of the lattice arches is equal to $1.5 \mathrm{~m}$ (Fig. 3).

Сакните Т., Сердюк Д.О., Горемыкин В.В., Пакрастиньш Л., Ватин Н.И. Проектирование огнестойких арочных деревянных покрытий // Инженерно-строительный журнал. 2016. № 4(64). С. 26-39. 


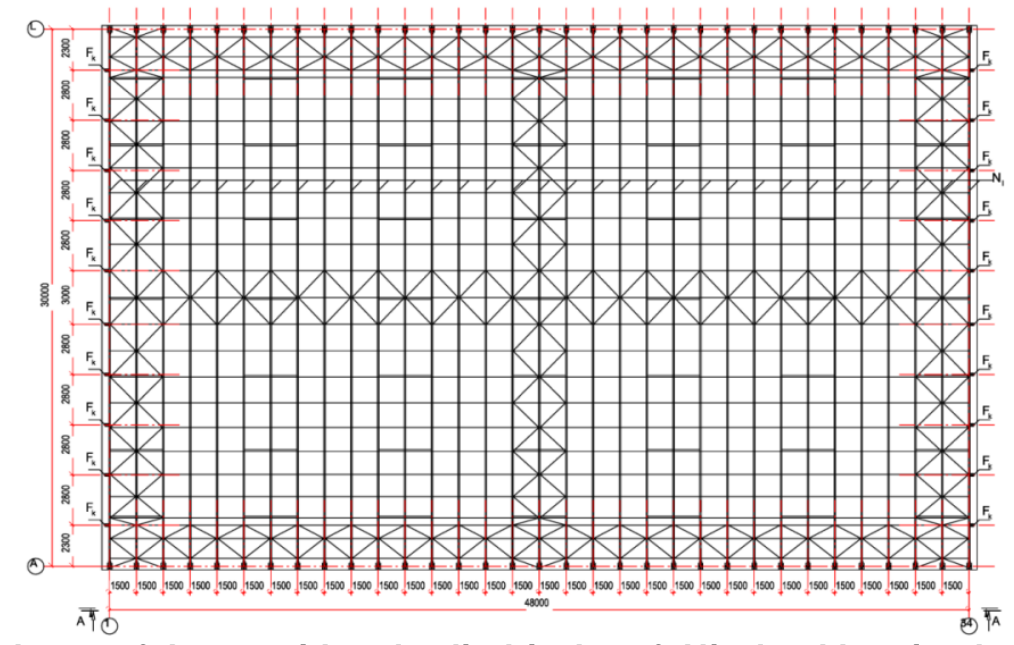

Figure 3. Scheme of the considered cylindrical roof: $\mathrm{Nj}$ - load-bearing lattice arches; $\mathrm{Fk}$ - columns of the framework

The lattice arch has rational geometrical parameters in terms of materials consumption, which were evaluated in the course of the previous investigation [6]. The height of the arch, depth of the arch cross-section, and distance between the nodes on the top chord were equal to $7.5,1.0$, and $1.5 \mathrm{~m}$ respectively (Fig. 4).

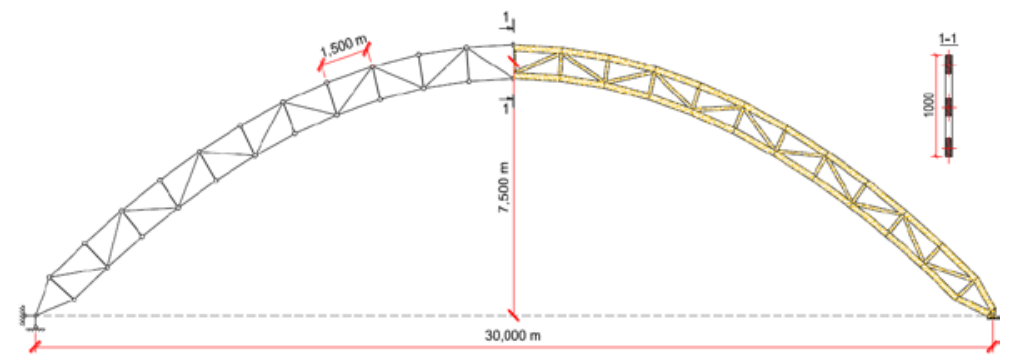

Figure. 4. Lattice arches with the nodes made of punched metal plates

All members of the arch are made of $\mathrm{C} 24$ strength class solid timber. The cross-section depth and width of the top and bottom chords of the arch are equal to 180 and $70 \mathrm{~mm}$ respectively. All elements of the lattice have equal dimensions of the cross-section: depth and width are equal to 100 and $70 \mathrm{~mm}$ respectively. The lattice arch elements are joined with the punched steel plates Kartro. The thickness and teeth length of the Kartro punched steel plates are equal to 1.2 and $12 \mathrm{~mm}$ respectively. The top and bottom chords of lattice arches are joined with freely supported solid timber purlins, which were placed with the step equal to $1.5 \mathrm{~m}$. The purlins with cross-section dimensions equal to $120 \times 70 \mathrm{~mm}$ and $100 \times 70 \mathrm{~mm}$ join the top and bottom chords of arches respectively. The strength class of solid timber is C24. Profiled steel sheets are the main load-bearing elements of the roofing [6].

The considered roof is analysed for Latvian climatic conditions [7]. The current place is the city of Riga. The characteristic values of permanent snow and wind loads were equal to $0.37,1.25$, and $0.56 \mathrm{kN} / \mathrm{m}^{2}$ respectively.

The aim of this study is to evaluate rational geometrical parameters of the above mentioned lattice timber arch with the punched steel plated joints. The lattice timber arch is the main load-bearing structure of the considered arch-type timber roof. Fire resistance and the possibility to increase it for the arch-type timber roof should also be considered.

\section{Methods and results}

\section{Choice of a design method}

The object of investigation, considered in this study, is a timber framework of cylindrical roof. It means that mechanical resistance, or criteria $\mathrm{R}$, will be considered as determinant parameters, which reflect fire resistance of object of investigation [8, 9]. Design procedures for mechanical resistance explained in EN 1995-1-2 include:

- reduced cross-section method;

Saknite T., Serdjuks D., Goremikins V., Pakrastins L., Vatin N.I. Fire design of arch-type timber roof. Magazine of Civil Engineering. 2016. No. 4. Pp. 26-39. doi: 10.5862/MCE.64.3 
- reduced properties method;

- parametric design method.

Choice of the method for fire resistance analyse was carried out on the base of results comparison, which were obtained by the reduced cross-section method, reduced properties method and by the published experimental results $[10,11]$. The two mentioned methods were chosen due to its simplicity, which is significant advantage in the case of big volume of calculations. The experimental results were obtained for the glued laminated timber beams with dimensions of cross-section 190X266 mm [8]. Value of the mean timber density changes within the limits from 300 to $464 \mathrm{~kg} / \mathrm{m}^{3}$. The beams were exposed to fire action from three sides. The charring rates and depths were fixed after 30, 45 and 60 minutes.

The experimental results indicate that charring rates and depths differed for the sides and bottom surfaces. So, for the side surfaces charring depth changes from 19.70 to $22.50 \mathrm{~mm}$, from 26.40 to $28.90 \mathrm{~mm}$ and from 42.10 to $45.90 \mathrm{~mm}$ for the times of fire exposure equal to 30,45 and $60 \mathrm{~min}$, correspondingly. Charring depth changes from 20.00 to $26.90 \mathrm{~mm}$, from 27.70 to $31.90 \mathrm{~mm}$ and from 46.00 to $49.00 \mathrm{~mm}$ for the times of fire exposure equal to 30,45 and $60 \mathrm{~min}$, correspondingly, for the bottom surfaces. The charring rates changes within the limits from 0.587 to $0.757 \mathrm{~mm} / \mathrm{min}$ and from 0.614 to $0.897 \mathrm{~mm} / \mathrm{min}$ for the side and bottom surfaces of the beams, correspondingly. The mean value of design notional charring rate that was obtained by the experiment was equal to $0.71 \mathrm{~mm} / \mathrm{min}$, what is much closed to the value $0.7 \mathrm{~mm} / \mathrm{min}$, which is given in EN 1995-1-2. Notional charring depth was determined by the following equation [10]:

$$
d_{\text {char }, n}=\beta_{n} \cdot t,
$$

where $\beta_{\mathrm{n}}$ - design notional charring rate; $t$ - time of fire exposure.

Effective charring depth is determined by the equation:

$$
d_{e f}=d_{c h a r, n}+k_{0} \cdot d_{0}
$$

where $d_{\mathrm{char}, \mathrm{n}}$ - notional charring depth; $k_{0}$ - coefficient; $d_{0}$ - depth of layer with assumed zero strength and stiffness.

The value of coefficient $k_{0}$ was taken equal to 1.0 for non-protected surfaces for the time of fire exposure bigger than 20 minutes. Depth of the layer with assumed zero strength and stiffness $d_{o}$ was taken equal to $7 \mathrm{~mm}[10]$.

Area of residual cross-section of the element, which is subjected to fire from three sides, in accordance with the reduced cross-section method, must be determined by the formula:

$$
A_{e f}=\left(h-d_{e f}\right) \cdot\left(b-2 \cdot d_{e f}\right) \text {, }
$$

where $d_{\mathrm{ef}}$ - effective charring depth; $h$ and $b$ are depth and width of cross-section before fire exposure, correspondingly.

Area of residual cross-section of the element in accordance with the reduced stress and stiffness method must be determined by the formula:

$$
A_{e f}=\left(h-d_{c h a r, n}\right) \cdot\left(b-2 \cdot d_{c h a r, n}\right)
$$

Area of residual cross-section of the element, which was obtained by the experimental results, must be determined by the equation:

$$
A_{e f, \text { exp }}=\left(h-d_{\text {char }, \text { exp }, \text { bot }}\right) \cdot\left(b-2 \cdot d_{\text {char }, \text { exp }, \text { side }}\right),
$$

where $d_{\text {char,exp }}$ is the charring depth, which was determined by the experiment.

The values of effective charring depths and areas of the residual cross-sections, which were determined by the experiment and with the reduced cross-section and reduced strength and stiffness methods, are given in Table 1.

Сакните Т., Сердюк Д.О., Горемыкин В.В., Пакрастиньш Л., Ватин Н.И. Проектирование огнестойких арочных деревянных покрытий // Инженерно-строительный журнал. 2016. № 4(64). С. $26-39$. 
Table 1. The values of effective charring depths and areas of residual cross-sections [8].

\begin{tabular}{|c|c|c|c|c|c|c|c|}
\hline \multirow{2}{*}{ 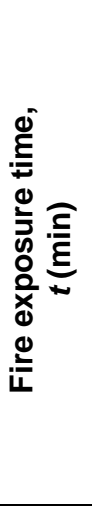 } & \multirow{2}{*}{ 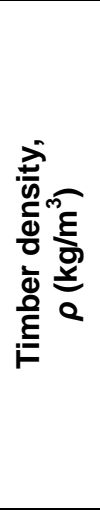 } & \multirow{2}{*}{ 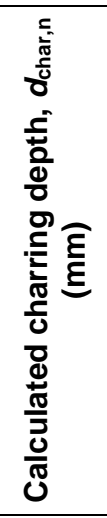 } & \multicolumn{2}{|c|}{$\begin{array}{l}\text { Experimentally obtained } \\
\text { charring depth, } \\
d_{\text {char,exp }}(\mathrm{mm})\end{array}$} & \multirow{2}{*}{ 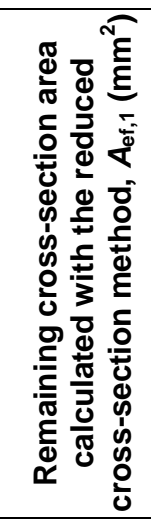 } & \multirow{2}{*}{ 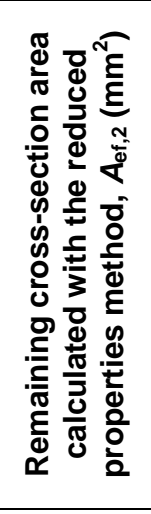 } & \multirow{2}{*}{ 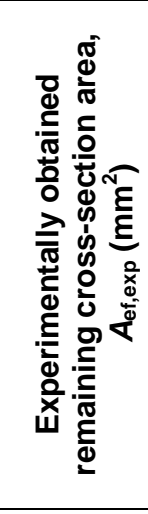 } \\
\hline & & & $\begin{array}{c}\text { Beam side } \\
\text { face }\end{array}$ & $\begin{array}{c}\text { Beam } \\
\text { bottom face }\end{array}$ & & & \\
\hline \multirow{3}{*}{30} & 399 & \multirow{3}{*}{21.00} & 22.50 & 26.90 & \multirow{3}{*}{31892.00} & \multirow{3}{*}{36260.00} & 34669.50 \\
\hline & 445 & & 21.30 & 22.60 & & & 35877.16 \\
\hline & 420 & & 19.70 & 20.00 & & & 37047.60 \\
\hline \multirow{3}{*}{45} & 411 & \multirow{3}{*}{31.50} & 26.40 & 31.90 & \multirow{3}{*}{25707.50} & \multirow{3}{*}{29781.50} & 32218.52 \\
\hline & 444 & & 28.90 & 29.00 & & & 31331.40 \\
\hline & 437 & & 27.40 & 27.70 & & & 32218.16 \\
\hline \multirow{3}{*}{60} & 412 & \multirow{3}{*}{42.00} & 43.40 & 46.00 & \multirow{3}{*}{19964.00} & \multirow{3}{*}{23744.00} & 22704.00 \\
\hline & 464 & & 42.10 & 46.80 & & & 23191.36 \\
\hline & 408 & & 45.40 & 49.00 & & & 21526.40 \\
\hline
\end{tabular}

The differences in percentage between the values of the residual cross-section, determined by the experiment and with the reduced cross-section and reduced strength and stiffness methods, are given in Figure 4.

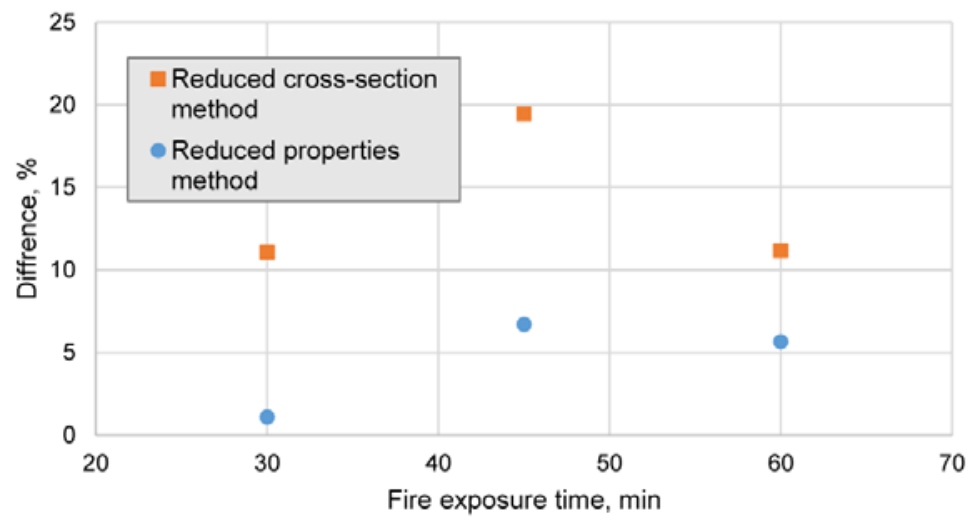

Figure 5. The differences in percentage between the values of the residual cross-section, determined by the experiment and with the reduced cross-section and reduced strength and stiffness methods

The comparison of results, obtained analytically and by the experiment, indicates that the values of the residual cross-sections, which were obtained with the reduced stress-stiffness method, differ from the experimentally obtained values by $0.76-4.82 \%$ [11]. Therefore, for the fire resistance analysis of the arch-type timber roof, the reduced stress-stiffness method will be used.

Simplified rules of designing connections, which are explained in section 6 of EN 1995-1-2, will be used for the joint analysis during the fire exposure.

\section{Design of fire-resistant arch-type timber roof}

\section{Design of fire-resistant purlins}

Let us start the design of the fire-resistant arch-type timber roof from the purlins. The purlins are placed in the planes of top and bottom chords of the considered lattice timber arch. The purlins are subject to dead weight, snow, and wind loads. Loading the purlins differed depending on their position in

Saknite T., Serdjuks D., Goremikins V., Pakrastins L., Vatin N.I. Fire design of arch-type timber roof. Magazine of Civil Engineering. 2016. No. 4. Pp. 26-39. doi: 10.5862/MCE.64.3 
the roof. Therefore, determination of the most heavy loaded purlins is the first stage of the analysis. Positions of the heaviest-loaded purlins are indicated in Figure 6 with red circles [6].

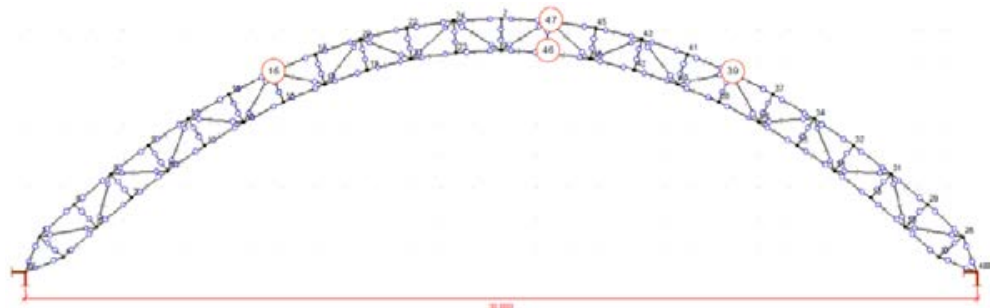

Figure 6. Nodes numbering of lattice timber arch and position of the heaviest loaded purlins

The heaviest loaded purlins are joined with the top chord of the lattice timber arch in nodes 16, 47, 39 and in node 46 with the bottom chord. Angles of the cross-sections inclinations are equal to 22 for the purlins joined with the lattice timber arch in nodes 16 and 39 and 5 for the purlins joined with the lattice timber arch in nodes 46 and 47 , correspondingly. The total load acting at the purlin in case of fire was determined by the equation [12]:

$$
G_{d, \text { sum }, f i}=\left(g_{k, 1}+g_{k, 2}\right) \cdot \gamma_{G, A}+q_{k, 1} \cdot \psi_{1},
$$

where $g_{\mathrm{k}, 1}$ - characteristic value of purlins dead weight; $g_{\mathrm{k}, 2}$ - characteristic value of dead weight of the roofing; $q_{k, 1}-$ characteristic value of snow load; $\gamma_{\mathrm{G}, \mathrm{A}}-$ load safety factor; $\psi_{1}$ - combination factor for variable load.

The values of load safety factor and combination factor for variable load were taked equal to 1.0 and 0.2 , correspondingly [12]. Geometrical parameters of purlins cross-sections in case of fire action were determined by the reduced strength and stiffness method (see Table 2). The purlins were considered as subjected to fire action from four sides.

Table 2. Geometrical parameters of purlins in case of fire action

\begin{tabular}{|c|c|c|c|c|}
\hline & \multicolumn{2}{|c|}{ Top chord purlines } & \multicolumn{2}{c|}{ Bottom chord purlines } \\
\hline $\boldsymbol{t}(\mathbf{m i n})$ & $\boldsymbol{h}_{\mathbf{f i}}(\mathbf{m m})$ & $\boldsymbol{b}_{\mathrm{fi}}(\mathbf{m m})$ & $\boldsymbol{h}_{\mathrm{fi}}(\mathbf{m m})$ & $\boldsymbol{b}_{\mathrm{fi}}(\mathbf{m m})$ \\
\hline 5 & 112.00 & 62.00 & 92.00 & 62.00 \\
\hline 8 & 107.20 & 57.20 & 87.20 & 57.20 \\
\hline 10 & 104.00 & 54.00 & 84.00 & 54.00 \\
\hline 13 & 99.20 & 49.20 & 79.20 & 49.20 \\
\hline 15 & 96.00 & 46.00 & 76.00 & 46.00 \\
\hline
\end{tabular}

The values of geometrical parameters of the purlins cross-sections were determined for the time of fire exposure equal to 5, 8, 10,13 and 15 minutes [8]. The purlins were analised at the fire action taking in to account strength and stability conditions. The strength of the purlins as the member subjected to compressing with the bending was checked by the equations (7) and (8) [13].

$$
\begin{aligned}
& \left(\sigma_{c, 0, d, f i} / f_{c, 0, d, f i}\right)^{2}+\sigma_{m, y, d, f i} / f_{m, y, d, f i}+k_{m} \cdot \sigma_{m, z, d, f i} / f_{m, z, d, f i} \leq 1, \\
& \left(\sigma_{c, 0, d, f i} / f_{c, 0, d, f i}\right)^{2}+k_{m} \cdot \sigma_{m, y, d, f i} / f_{m, y, d, f i}+\sigma_{m, z, d, f i} / f_{m, z, d, f i} \leq 1,
\end{aligned}
$$

where: $\sigma_{\mathrm{c}, \mathrm{o}, \mathrm{d}, \mathrm{fi}}-$ design compressive stress along the grain in case of fire action, $\sigma_{\mathrm{m}, \mathrm{y}, \mathrm{d}, \mathrm{fi}}-$ design bending stress about the principal $\mathrm{y}$-axis in case of fire action, $\sigma_{\mathrm{m}, \mathrm{z}, \mathrm{d}, \mathrm{fi}}-$ design bending stress about the principal $z$-axis in case of fire action, $f_{m, y, d, f i}$ - design bending strength about the principal $y$-axis in case of fire action, $f_{\mathrm{m}, \mathrm{z}, \mathrm{d}, \mathrm{fi}}$ - design bending strength about the principal $\mathrm{z}$-axis in case of fire action, $k_{\mathrm{m}}$ - factor, considering redistribution of bending stress in cross-section.

The stability of the purlins as the member subjected to compressing with the bending, was checked by the equations (9) and (10) [13].

Сакните Т., Сердюк Д.О., Горемыкин В.В., Пакрастиньш Л., Ватин Н.И. Проектирование огнестойких арочных деревянных покрытий // Инженерно-строительный журнал. 2016. № 4(64). С. $26-39$. 


$$
\begin{aligned}
& \sigma_{c, 0, d, f i} / k_{c, y, f i} f_{c, 0, d, f i}+\sigma_{m, y, d, f i} / f_{m, y, d, f i}+k_{m} \cdot \sigma_{m, z, d, f i} / f_{m, z, d, f i} \leq 1, \\
& \sigma_{c, 0, d, f i} / k_{c, z, f i} f_{c, 0, d, f i}+k_{m} \cdot \sigma_{m, y, d, f i} / f_{m, y, d, f i}+\sigma_{m, z, d, f i} / f_{m, z, d, f i} \leq 1,
\end{aligned}
$$

where $k_{\mathrm{c}, \mathrm{y}, \mathrm{fi}}$ is an instability factor along the principal $\mathrm{y}$-axis under fire impact, $k_{\mathrm{c}, \mathrm{z}, \mathrm{fi}}$ is an instability factor along the principal z-axis under fire impact; other designations are the same as for equations (7) and (8).

The dependence of fire-resistance on the time of fire exposure for the four heaviest-loaded purlins obtained by the strength condition is shown in Figure 7.

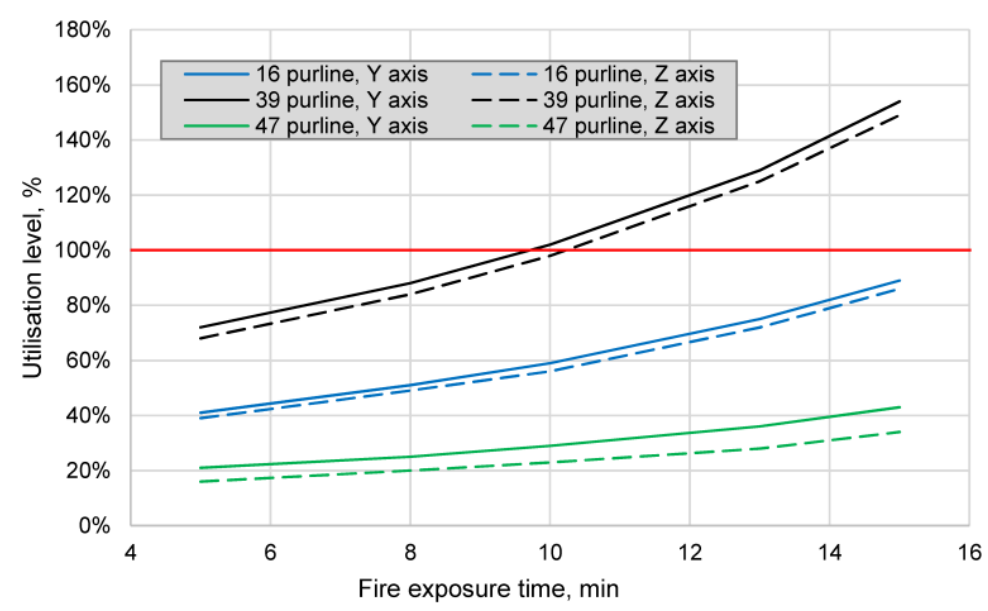

Figure 7. The utilisation level of purlins by strength criteria depending on fire exposure time

The dependence of fire-resistance on the time of fire exposure for the four heaviest-loaded purlins obtained by the stability condition is shown in Figure 8.

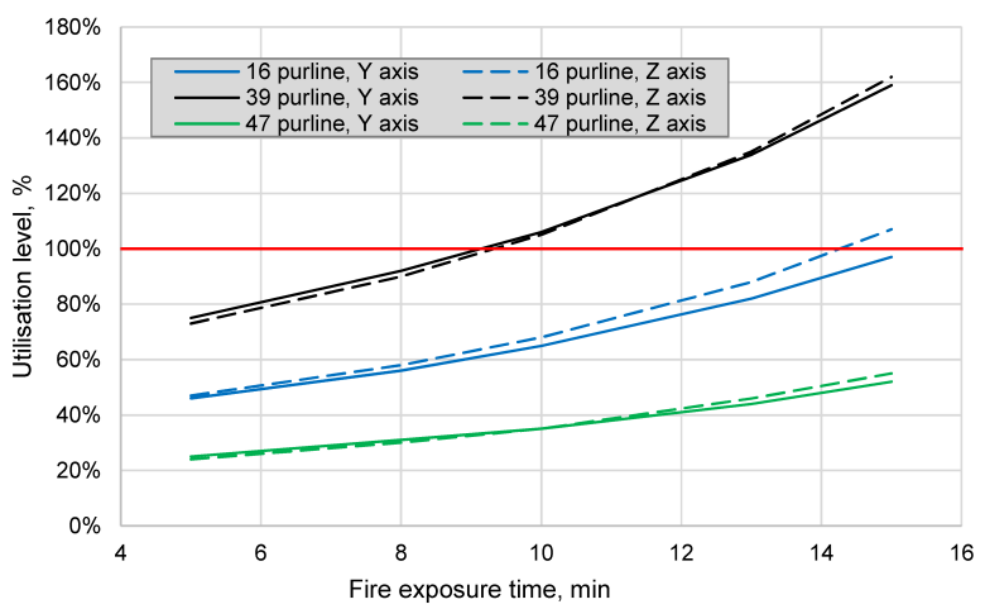

Figure 8. The utilisation level of purlins by strength criteria depending on fire exposure time

It was shown that the strength and stability conditions were not satisfied in 9.8 and 9.4 minutes of fire exposure respectively. The area of the residual cross-section of the purlins placed in the plane of the top chord of the lattice timber arch was equal to 82.7 and $52.6 \%$ of its initial value in 5 and 15 min of fire exposure respectively. It means that fire resistance of purlins is equal to R9.4, which is less than the minimum required value R15 $[8,9]$.

\section{Design of fire-resistant lattice arch members}

Analyzing fire-resistance of the lattice timber arch was carried out using the program AXIS VM 11 during the impact of the most unpleasant loads combination. The scheme of fire impact at the top chord of the lattice timber arch is shown in Figure 9. 


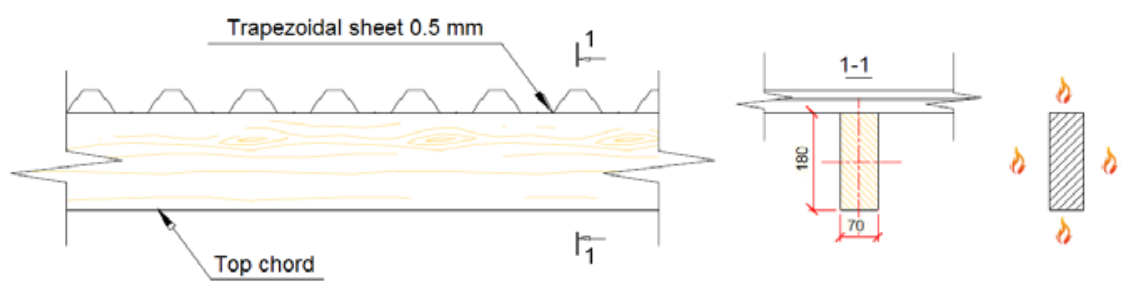

Figure 9. Scheme of fire impact at the top chord of the lattice timber arch

The element is exposed to fire from all four sides, as the profiled steel sheets of the roofing were not taken into account as a protective layer. Geometrical parameters of chords cross-sections in the case of fire exposure were determined with the reduced strength and stiffness method (see Table 3) [10].

Table 3. Geometrical parameters of purlins in the case of fire exposure

\begin{tabular}{|c|c|c|}
\hline \multicolumn{3}{|c|}{ Top chord purlines } \\
\hline $\mathbf{t}(\mathbf{m i n})$ & $\boldsymbol{h}_{\mathrm{fi}}(\mathbf{m m})$ & $\boldsymbol{b}_{\mathrm{fi}}(\mathbf{m m})$ \\
\hline 5 & 172.00 & 62.00 \\
\hline 8 & 167.20 & 57.20 \\
\hline 10 & 164.00 & 54.00 \\
\hline 13 & 159.20 & 49.20 \\
\hline 15 & 156.00 & 46.00 \\
\hline
\end{tabular}

The decrease in dimensions of the member cross-sections due to fire exposure has a significant influence on the load-bearing capacity of the timber lattice arch. The area of the residual cross-section of the chords element in $15 \mathrm{~min}$ of fire exposure is equal to $57 \%$ of the initial area of the cross-section. The area of the residual cross-section for the elements of the lattice is equal to $49.9 \%$ of its initial value in 15 minutes of fire exposure.

The values of geometrical parameters of the chords and cross-sections of lattice elements were determined for the time of fire exposure equal to $5,8,10,13$, and 15 minutes [8]. The elements were analysed under fire impact allowing for the strength and stability conditions [13]. The elements of the chords are subject to compression with bending. The elements of the lattice are loaded axially. The dependence of the sum of stress-to-strength relations on the time of fire exposure for the elements of the lattice timber arch obtained by the strength condition is shown in Figure 10.

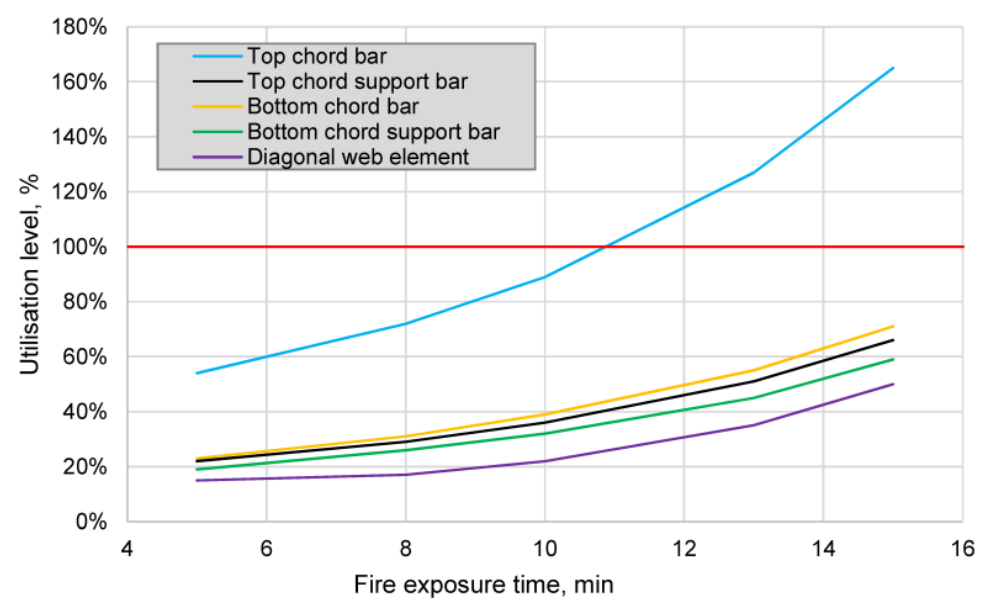

Figure 10. The utilisation level of arch elements by strength criteria depending on the fire exposure time

The dependence of the sum of stress-to-strength relations from the time of fire exposure for the elements of the lattice timber arch obtained by the stability condition relative to $y$-axis is shown in Figure 11.

Сакните Т., Сердюк Д.О., Горемыкин В.В., Пакрастиньш Л., Ватин Н.И. Проектирование огнестойких арочных деревянных покрытий // Инженерно-строительный журнал. 2016. № 4(64). С. $26-39$. 


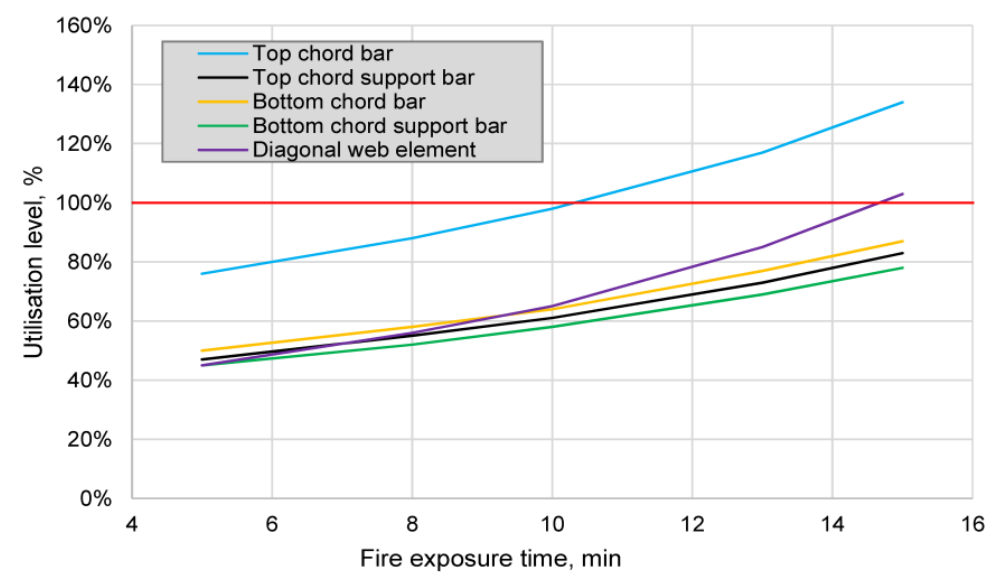

Figure 11. The utilisation level of arch elements by stability criteria relative to $\mathrm{Y}$ axis depending on fire exposure time

The dependence of the sum of stress-to-strength relations from the time of fire exposure for the elements of the lattice timber arch obtained by the stability condition relative to z-axis is shown in Figure 12.

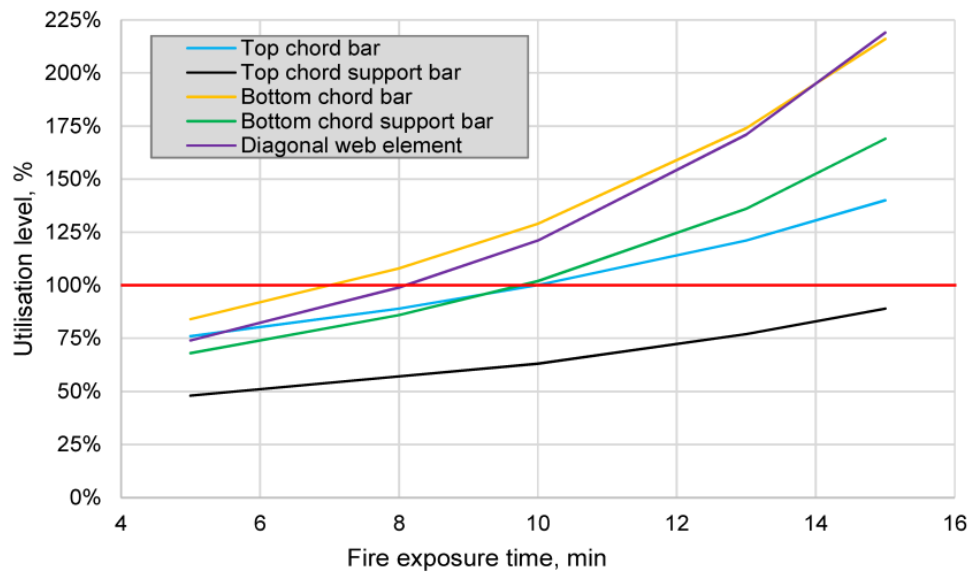

Figure 12. The utilisation level of arch elements by stability criteria relative to $Z$ axis depending on fire exposure time

The dependence indicates that the strength condition for the top chord of the timber lattice arch is not satisfied just in 11.1 minutes of fire exposure. The buckling of the top chord occurs in 10.5 minutes of fire exposure relative to $y$-axis. The buckling of the bottom chord occurs in 7.2 minutes of fire exposure relative to z-axis. It means that fire resistance of the lattice timber arch is equal to $\mathrm{R7.2,} \mathrm{which} \mathrm{is} \mathrm{more}$ than twice less, than the minimum required value R15 [8].

Design of fire-resistant lattice arch joints

Punched steel plates KARTRO with zinc coating with thickness $1.2 \mathrm{~mm}$ and length of teeth in $12 \mathrm{~mm}$ were considered as a type of fasteners for the joints of the lattice timber arch. Steel of punched plates just after 7.5-8.5 minutes of standard fire exposure come in to a plastic stage. Fire resistance of unprotected joint must be determined by the equation [10]:

$$
t_{d, f i}=-1 / k \cdot \ln \left(\eta_{f i} \gamma_{M, f i} / \gamma_{M} k_{f i}\right) \text {, }
$$

where $k$ - is a constant parameter, which depends on the type of joint, $\eta_{\mathrm{fi}}$ is a reduction factor; $\gamma_{\mathrm{M}, \mathrm{fi}}$ is a partial factor for timber under fire impact, $\gamma_{\mathrm{M}}$ is a partial factor for material properties .

Fire resistance of the lattice timber arch joints was evaluated as 8.61 minutes. So, it can be concluded that fire resistance of the whole roof can be evaluated as R7.2, which is more than twice less than the minimum required value R15 [8]. Fire resistance increase to the minimum required level R15 will be considered in the next chapter of the paper. 


\section{Discussion}

\section{Fire resistance increase of timber roof's load-bearing members}

Fire resistance of purlins can be increased by the increasing of depths of its cross-sections [14]. It was shown that the minimum required level of fire resistance $\mathrm{R} 15$ can be obtained if the depth of purlins cross-sections will be increased to $180 \mathrm{~mm}$. So, considered dimensions of the purlins cross-sections are $180 \times 70 \mathrm{~mm}$.

The width of member cross-sections must be increased to provide the necessary fire resistance R15 for the lattice timber arch. But this possibility is limited due to the small typical dimensions of members: 45, 60, and $70 \mathrm{~mm}$. The greater width of cross-section can be provided if several arches will be placed together one next to the other (see Fig. 13).

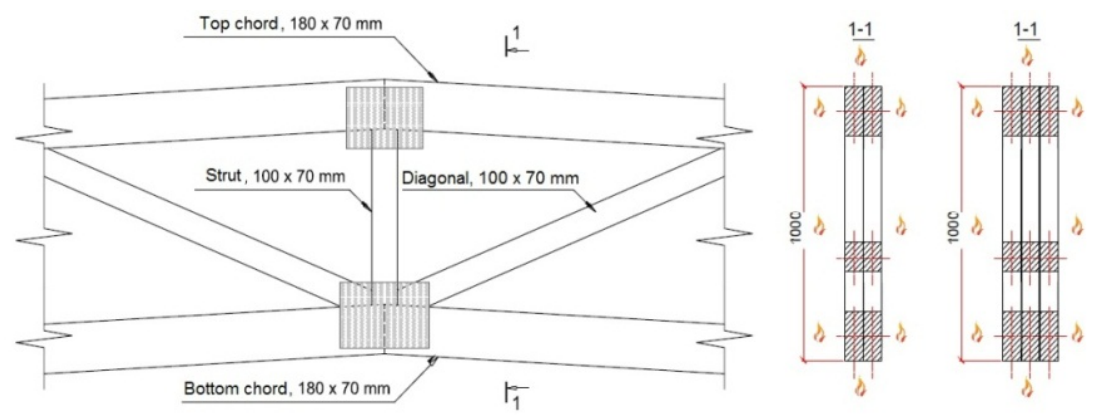

Figure 13. Increase of the width of lattice arch by placing one arch next to the other

The cases when two and three lattice timber arches are placed together, were considered in this study. The clearances between the arches were equal to $2.4 \mathrm{~mm}$ because the nodes were created with the punched steel plates with the thickness equal to $1.2 \mathrm{~mm}$. So, all the arches were considered under fire impact from the four sides. It was shown that the necessary fire resistance R15 can only be provided for three arches placed together. Fire resistance of two arches placed together is only limited by R14.5.

Protective covering is another way to provide the necessary level of fire resistance for the lattice timber arch (see Fig. 14). It was shown that the necessary fire resistance R15 can be provided if the arch is covered with plywood sheets with the thickness of $12 \mathrm{~mm}[10,15]$. The density of the considered plywood is equal to $715 \mathrm{~kg} / \mathrm{m}^{3}$.

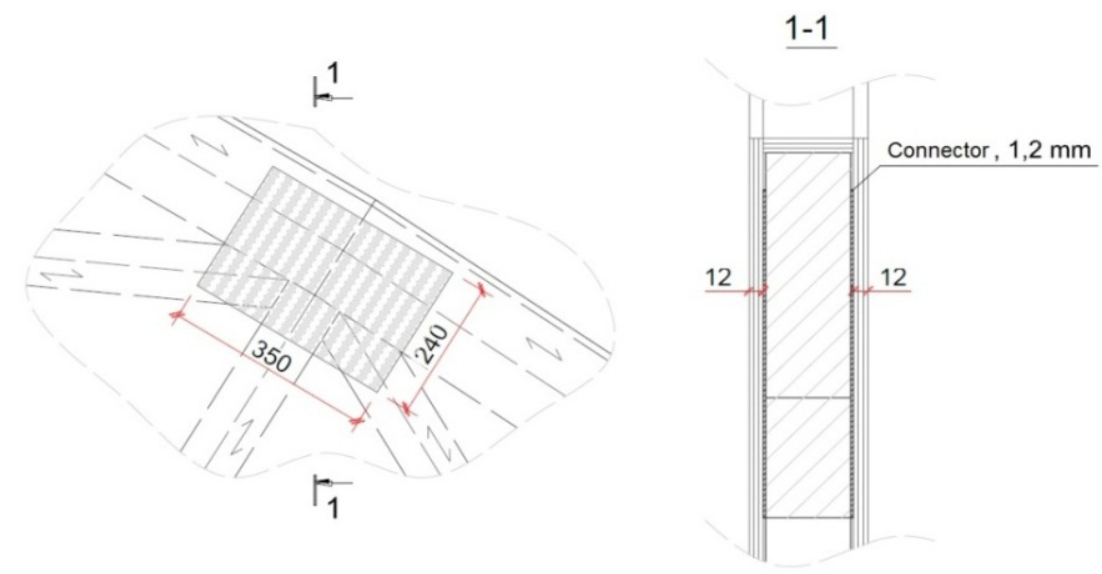

Figure 14. Protective covering of lattice arch by the plywood sheets with thickness in $12 \mathrm{~mm}$.

Thickness of the plywood sheets in $12 \mathrm{~mm}$ was determined basing on the condition:

$$
a_{f i}=\beta_{n} \cdot k_{\text {flux }} \cdot\left(t_{\text {req }}-t_{d, f i}\right),
$$

where $a_{\mathrm{fi}}$ is minimum required thickness of the protective layer, $\beta_{\mathrm{n}}$ is a charring rate for plywood, $k_{\mathrm{flux}}$ is a constant factor, $t_{\text {req }}$ is a required characteristic value of fire resistance, $t_{\mathrm{d}, \mathrm{fi}}$ is fire resistance of an unprotected joint.

Сакните Т., Сердюк Д.О., Горемыкин В.В., Пакрастиньш Л., Ватин Н.И. Проектирование огнестойких арочных деревянных покрытий // Инженерно-строительный журнал. 2016. № 4(64). С. $26-39$. 
The values of a charring rate for plywood, the constant factor, the required characteristic value of fire resistance, and fire resistance of an unprotected joint were equal to $1.02 \mathrm{~mm} / \mathrm{min}, 1.5,15 \mathrm{~min}$, and 7.5 min respectively. The minimum required thickness of the protective layer, which had been obtained by equation (12), was equal to $11.48 \mathrm{~mm}$. So, the thickness of the protective layer was taken as $12 \mathrm{~mm}$.

The comparison of the effectiveness of elements cross-sections increase and the protective layer usage for the fire resistance increase is given in Figure 15.

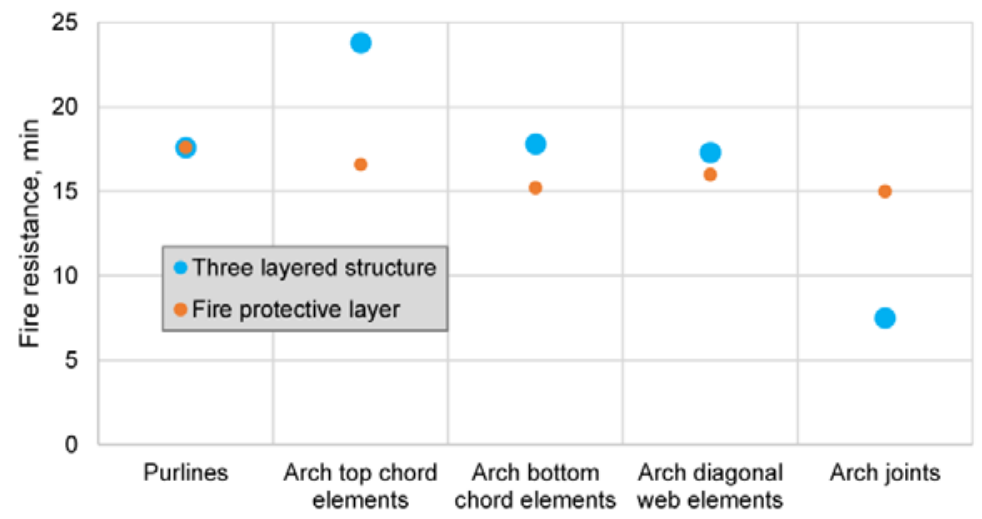

Figure 15. Comparison of the effectiveness of element cross-section increase and the protective layer usage for the fire resistance increase

The increase in element cross-sections cause the growth of the lattice timber arches materials consumption from 1.307 to $3.921 \mathrm{~m}^{3}$ when three arches are placed together one next to the other. The protective layer usage causes the growth of the lattice timber arches materials consumption from 1.307 to $2.163 \mathrm{~m}^{3}$. But the elements cross-section increase did not allow protecting the nodes of the edge arches, as it is shown in Figure 15. Therefore, based on the comparison of both methods, the usage of protective layer is considered as a preferable method of fire resistance increase for the lattice timber arch [16].

\section{Evaluation of rational parameters of the arch-type timber roof}

The response surface method was used to evaluate rational values of the main geometrical parameters of the arch-type timber roof $[17,18]$. The height of the arch (f), depth of the arch crosssection (h), and distance between the nodes on the top chord (a) are considered as the main geometrical parameters (Fig. 16.).

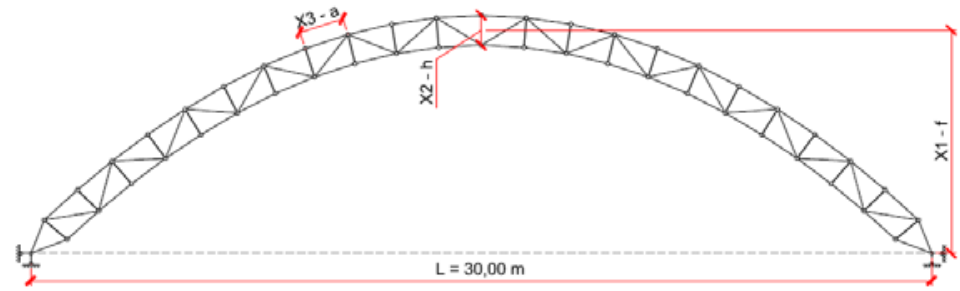

Figure 16. The main geometrical parameters of arch-type timber roof: (f) height of the arch; (h) depth of the arch cross-section; (a) distance between the nodes on the top chord.

Materials consumption of purlins and lattice timber arch so as maximum axial force acting in the top chord of the arch were considered as the parameters of optimization [19]. The dependences of the main geometrical parameters of the arch-type timber roof on the material consumption were determined as the second order polynomial equations in case of fire action and without taking in to consideration the fire action.

$$
Y^{\prime}=b_{0}+b_{1} f+b_{2} h+b_{3} a+b_{12} f h+b_{13} f a+b_{23} h a+b_{123} f X_{2} a+b_{11} f^{2}+b_{22} h^{2}+b_{33} a^{2},
$$

where $Y^{\prime}$ is materials consumption $\left(\mathrm{m}^{3}\right) ; f$ is height of the $\operatorname{arch}(\mathrm{m}) ; h$ is depth of the arch cross-section $(\mathrm{m}) ; a$ is a distance between the nodes on the top chord $(\mathrm{m})$.

The values of the height of the arch, depth of the arch cross-section, and the distance between the nodes on the top chord change within the limits from 5.5 to $7.5 \mathrm{~m}$, from 0.5 to $1 \mathrm{~m}$, and from 1 to $1.5 \mathrm{~m}$ respectively. Coefficients of the second order polynomial equations are given in the table.

Saknite T., Serdjuks D., Goremikins V., Pakrastins L., Vatin N.I. Fire design of arch-type timber roof. Magazine of Civil Engineering. 2016. No. 4. Pp. 26-39. doi: 10.5862/MCE.64.3 
Table 4. Coefficients of the second order polynomial equations

\begin{tabular}{|c|c|c|c|c|}
\hline & \multicolumn{2}{|c|}{ In the context of material consumption } & \multicolumn{2}{|c|}{$\begin{array}{l}\text { In the context of axial forces in the arch top } \\
\text { chord }\end{array}$} \\
\hline & $\begin{array}{l}\text { Fire is not taken into } \\
\text { account }\end{array}$ & $\begin{array}{l}\text { Fire is taken into } \\
\text { account }\end{array}$ & $\begin{array}{l}\text { Fire is not taken into } \\
\text { account }\end{array}$ & $\begin{array}{l}\text { Fire is taken into } \\
\text { account }\end{array}$ \\
\hline$b_{0}$ & 9.46184 & 10.9741 & 547.358 & 551.152 \\
\hline$b_{1}$ & -1.50739 & -1.37964 & -22.7047 & -23.5849 \\
\hline$b_{2}$ & -5.69789 & -6.27883 & -411.36 & -407.507 \\
\hline$b_{3}$ & -1.44156 & -3.74211 & -123.181 & -124.552 \\
\hline$b_{12}$ & 0.304 & 0.397667 & -0.262333 & -0.711667 \\
\hline$b_{13}$ & 0.07 & 0.231333 & 1.528 & 1.30067 \\
\hline$b_{23}$ & -1.956 & -3.01333 & -5.87333 & -5.21467 \\
\hline$b_{123}$ & 0.0 & 0.0 & 0.0 & 0.0 \\
\hline$b_{11}$ & 0.0872222 & 0.0575 & 0.9335 & 1.03778 \\
\hline$b_{22}$ & 3.52622 & 4.776 & 190.216 & 190.946 \\
\hline$b_{33}$ & 1.13156 & 1.992 & 46.5093 & 47.4604 \\
\hline
\end{tabular}

Values of coefficients of the second order polynomial equations were determined with the EdaOpt computational program [20]. The obtained polynomial equations enable describing the obtained results

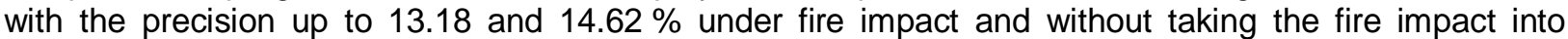
consideration.

The dependence of the height of the arch ( $f$ ) and depth of the arch cross-section (h) on the materials consumption under fire impact and without taking the fire impact into consideration is given in Figure 17.

a)

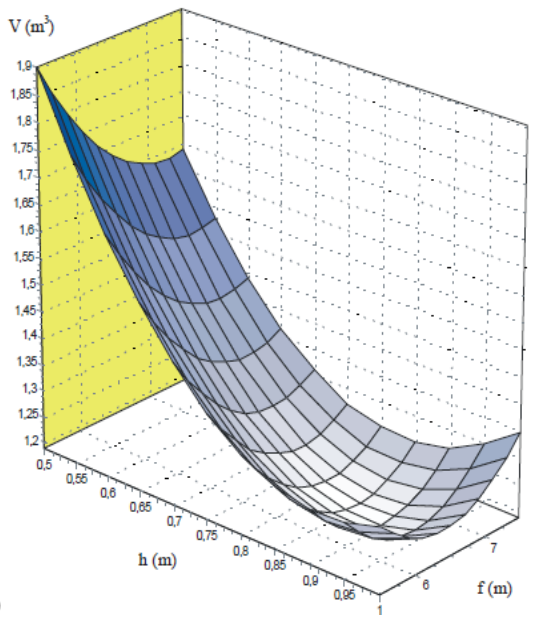

b)

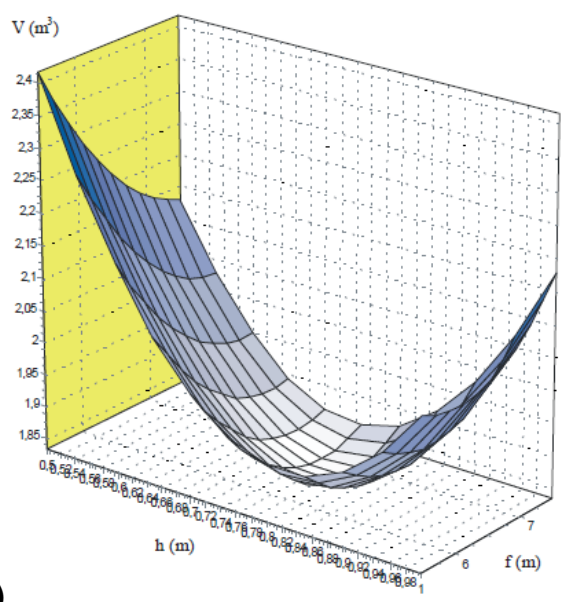

Figure 17. The dependences of height of the arch (f) and depth of the arch cross-section (h) on the materials consumption in case of fire action a) and without taking in to consideration the fire action b).

The rational from the point of view of materials consumption values of height of the arch, depth of the arch cross-section and distance between the nodes on the top chord were determined by the system of equations [16]:

$$
\left\{\begin{array}{l}
\frac{\partial G}{\partial f}=b_{1}+b_{12} h+b_{13} a+b_{123} h a+2 b_{11} f=0 \\
\frac{\partial G}{\partial h}=b_{2}+b_{12} f+b_{23} a+b_{123} f a+2 b_{22} h=0 \\
\frac{\partial G}{\partial a}=b_{3}+b_{13} f+b_{23} h+b_{123} f h+2 b_{33} a=0
\end{array}\right.
$$

Сакните Т., Сердюк Д.О., Горемыкин В.В., Пакрастиньш Л., Ватин Н.И. Проектирование огнестойких арочных деревянных покрытий // Инженерно-строительный журнал. 2016. № 4(64). С. $26-39$. 
The rational values of the height of the arch, depth of the arch cross-section, and the distance between the nodes on the top chord were given in Table 5.

Table 5. Rational values of geometrical parameters of the arch-type timber roof

\begin{tabular}{|c|c|c|c|}
\hline Variable factors & & $\begin{array}{l}\text { In the context of } \\
\text { material consumption }\end{array}$ & $\begin{array}{l}\text { In the context of axial } \\
\text { forces in the arch top } \\
\text { chord }\end{array}$ \\
\hline \multicolumn{4}{|c|}{ Fire is not taken into account } \\
\hline$X_{1}-f$ & Arch axe camber (m) & 6.70 & $11.30 *$ \\
\hline$X_{2}-h$ & $\begin{array}{l}\text { Arch cross-section height } \\
(\mathrm{m})\end{array}$ & 0.80 & $1.10^{*}$ \\
\hline$x_{3}-a$ & $\begin{array}{l}\text { Arch top chord segment } \\
\text { length }(\mathrm{m})\end{array}$ & 1.15 & 1.2 \\
\hline \multicolumn{4}{|c|}{ Fire is taken into account } \\
\hline$X_{1}-f$ & Arch axe camber (m) & $7.85^{\star}$ & $10.95^{\star}$ \\
\hline$x_{2}-h$ & $\begin{array}{l}\text { Arch cross-section height } \\
(\mathrm{m})\end{array}$ & 0.6 & $1.10^{*}$ \\
\hline$x_{3}-a$ & $\begin{array}{l}\text { Arch top chord segment } \\
\text { length }(\mathrm{m})\end{array}$ & $0.95^{\star}$ & 1.2 \\
\hline
\end{tabular}

It can be concluded that the finally adopted rational values of the height of the arch (f), depth of the arch cross-section (h), and distance between the nodes on the top chord (a) are equal to $7.85,1.10$ and $0.95 \mathrm{~m}$ respectively.

\section{Conclusions}

The paper considers the possibility of a fire resistance increase to R15 for the arch-type timber roof by using the protective layer and increase in the elements cross-sections dimensions. Using the protective layer is considered as a preferable method of the fire resistance increase for the lattice timber arch because it is joined with the growth of materials consumption by 1.65 times. The increase in the elements cross-sections dimensions causes the growth of materials consumption by 3 times.

Rational values of the height of the arch, depth of the arch cross-section, and distance between the nodes on the top chord were evaluated for the arch-type timber roof with the response surface method. Fire resistance of the roof was taken into account. The span of the considered arch-type timber roof was equal to $30 \mathrm{~m}$. The values of the height of the arch, depth of the arch cross-section, and distance between the nodes on the top chord change within the limits from 5.5 to $7.5 \mathrm{~m}$, from 0.5 to $1 \mathrm{~m}$, and from 1 to $1.5 \mathrm{~m}$ respectively. It was shown that the rational values of the height of the arch, depth of the arch cross-section, and distance between the nodes on the top chord are equal to $7.85,1.10$, and $0.95 \mathrm{~m}$ respectively. The corresponding minimum material consumptions were equal to 1.856 and $1.273 \mathrm{~m}^{3}$ in case of fire impact and without taking it into consideration.

\section{Acknowledgement}

The research leading to these results has received its funding from the Latvia state research program under the grant agreement "Innovative Materials and Smart Technologies for Environmental Safety, IMATEH". Project Nr.3, PVS ID1854, Task Nr.3.

\section{References}

1. Ozola L. Konektoru kopņu projektēšana. Elgava: LLU, 1999. $62 \mathrm{p}$.

2. Serdjuks D., Goremikins V., Šliseris J. Metodiskie norādījumi priekšmetā BBK 560 „Koka un plastmasu konstrukcijas" (speciālais kurss). Riga: RTU, 2012. 46 p.

3. Goremikins V., Šejnoha J., Wald F., Bednar J. Analytical model of composite floors with steel fibre reinforced concrete slab subjected to fire. Journal of Civil Engineering and Management. November 2015. Pp. 1-9.

4. Frangi A., Fontana M., Hugi E., Jübstl R. Experimental analysis of cross-laminated timber panels in fire. Fire Safety

\section{Литература}

1. Ozola L. Konektoru kopņu projektēšana. Elgava: LLU, 1999. $62 \mathrm{p}$.

2. Serdjuks D., Goremikins V., Šliseris J. Metodiskie norādijumi priekšmetā BBK 560 „Koka un plastmasu konstrukcijas" (speciālais kurss). Riga: RTU, 2012. 46 p.

3. Goremikins V., Šejnoha J., Wald F., Bednar J. Analytical model of composite floors with steel fibre reinforced concrete slab subjected to fire // Journal of Civil Engineering and Management. November 2015. Pp. 1-9.

4. Frangi A., Fontana M., Hugi E., Jübstl R. Experimental analysis of cross-laminated timber panels in fire // Fire

Saknite T., Serdjuks D., Goremikins V., Pakrastins L., Vatin N.I. Fire design of arch-type timber roof. Magazine of Civil Engineering. 2016. No. 4. Pp. 26-39. doi: 10.5862/MCE.64.3 
Journal. 2009. No. 44(8). Pp. 1078-1087.

5. Frangi A., Knobloch M., Fontana M. Fire design of timber slabs made of hollow core elements. Engineering Structures. 2009. No. 31(1). Pp. 150-157.

6. Saknite T. Lokveida koka kopnes racionāla risinājuma pamatojums. Riga: RTU, 2014. 187 p.

7. LBN 201-15. Būvju ugunsdrošỉba. Riga. 2015. 33 p.

8. LBN 003-01. Būvklimatoloǵija. Riga, 2001. 50 p.

9. Gravit M., Vaitickii A, Imasheva M., Nigmatulina D., Shpakova A. Classification of Fire Technical Characteristic of Roofing Materials in European and Russian Regulation Documents. MATEC Web of Conferences. 2016.

10. EN 1995-1-2. Eurocode 5: Design of timber structures. Part 1-2: General - Structural fire design. Brussels: European Committee for Standardisation, 2004. $69 \mathrm{p}$.

11. Yang T.H. The charring depth and charring rate of glued laminated timber after a standard fire exposure test. Building and Environment. 2009. No. 44 (2), Pp. 231-236.

12. EN 1990. Eurocode 0: Basis of structural design. Brussels: European Committee for Standardisation, 2002. $69 \mathrm{p}$.

13. EN 1995-1-1. Eurocode 5: Design of timber structures. Part 1-1: General - Common Rules and Rules for Buildings. Brussels: European Committee for Standardisation, 2004. $123 \mathrm{p}$.

14. Serdjuks D., Goremikins V. Ugunsdrošu koka konstrukciju projektēšana saskañā ar LVS EN 1995-1-2. Metodiskie noradijumi. Riga: RTU, 2014. 46 p.

15. Krivtcov A., Gravit M., Zimin S., Nedryshkin O., Pershakov V. Calculation of Fire Resistance for Structures with Fire Retardant Coating. MATEC Web of Conferences. 2016.

16. Saknite T. Lokveida koka pārseguma ugunsizturïbas analïze. Riga: RTU, 2015. 100 p.

17. Hirkovskis A., Serdjuks D., Goremikins V., Pakrastins L., Vatin N.I. Behaviour analysis of load-bearing aluminium members. Magazine of Civil Engineering. 2015. No. 5. Pp. 86-96.

18. Villar J.R., Vidal P., Fernández M.S., Guaita M. Genetic algorithm optimisation of heavy timber trusses with dowel joints according to Eurocode 5. Biosystems Engineering. 2016. No. 144. Pp. 115-132

19. Goremikins V., Rocens K., Serdjuks D., Pakrastins L., Vatin $\mathrm{N}$. Cable truss topology optimization for prestressed longspan structure. Advances in Civil Engineering and Building Materials IV. 2014. Pp. 363-368.

20. Auzukalns J. Manual of software EdaOpt. Riga: RTU. 2007.

Tatjana Saknite,

+37167089145; tatjana.saknite@rtu.Iv

Dmitrijs Serdjuks,

+37126353082; Dmitrijs.Serdjuks@rtu.Iv

Vadims Goremikins,

+37129231772; goremikins@gmail.com

Leonids Pakrastins,

+37129452138; leonids.pakrastins@rtu.Iv

Nikolai Vatin,

+79219643762; vatin@mail.ru
Safety Journal. 2009. № 44(8). Pp. 1078-1087.

5. Frangi A., Knobloch M., Fontana M. Fire design of timber slabs made of hollow core elements // Engineering Structures. 2009. № 31(1). Pp. 150-157.

6. Saknite T. Lokveida koka kopnes racionāla risinājuma pamatojums. Riga: RTU, 2014. 187 p.

7. LBN 201-15. Būvju ugunsdrošība. Riga. 2015. 33 p.

8. LBN 003-01. Būvklimatoloǵija. Riga, 2001. 50 p.

9. Gravit M., Vaitickii A, Imasheva M., Nigmatulina D., Shpakova A. Classification of Fire Technical Characteristic of Roofing Materials in European and Russian Regulation Documents // MATEC Web of Conferences. 2016.

10. EN 1995-1-2. Eurocode 5: Design of timber structures. Part 1-2: General - Structural fire design. Brussels: European Committee for Standardisation, 2004. 69 p.

11. Yang T.H. The charring depth and charring rate of glued laminated timber after a standard fire exposure test /I Building and Environment. 2009. № 44 (2), Pp. 231-236.

12. EN 1990. Eurocode 0: Basis of structural design. Brussels: European Committee for Standardisation, 2002. $69 \mathrm{p}$.

13. EN 1995-1-1. Eurocode 5: Design of timber structures. Part 1-1: General - Common Rules and Rules for Buildings. Brussels: European Committee for Standardisation, 2004. $123 \mathrm{p}$.

14. Serdjuks D., Goremikins V. Ugunsdrošu koka konstrukciju projektēšana saskañā ar LVS EN 1995-1-2. Metodiskie noradijumi. Riga: RTU, 2014. 46 p.

15. Krivtcov A., Gravit M., Zimin S., Nedryshkin O., Pershakov V. Calculation of Fire Resistance for Structures with Fire Retardant Coating // MATEC Web of Conferences. 2016

16. Saknite T. Lokveida koka pārseguma ugunsizturības analīze. Riga: RTU, 2015. 100 p.

17. Hirkovskis A., Serdjuks D., Goremikins V., Pakrastins L., Vatin N.I. Behaviour analysis of load-bearing aluminium members // Magazine of Civil Engineering. 2015. № 5 . Pp. 86-96.

18. Villar J.R., Vidal P., Fernández M.S., Guaita M. Genetic algorithm optimisation of heavy timber trusses with dowel joints according to Eurocode 5 // Biosystems Engineering. 2016. № 144. Pp. 115-132

19. Goremikins V., Rocens K., Serdjuks D., Pakrastins L., Vatin N. Cable truss topology optimization for prestressed longspan structure. Advances in Civil Engineering and Building Materials IV. 2014. Pp. 363-368.

20. Auzukalns J. Manual of software EdaOpt. Riga: RTU. 2007.

Татьяна Сакните,

+37167089145; эл. почта: tatjana.saknite@rtu.Iv

Дмитрий Олегович Сердюк, +37126353082; эл. почта:

Dmitrijs.Serdjuks@rtu.Iv

Вадим Валерьевич Горемыкин, +37129231772; эл. почma:goremikins@gmail.com

\author{
Леонид Пакрастиньш, \\ +37129452138; эл. почта: \\ leonids.pakrastins@rtu.Iv
}

Николай Иванович Ватин, +79219643762; эл. почта: vatin@mail.ru

(C) Saknite T., Serdjuks D., Goremikins V., Pakrastins L., Vatin N.I., 2016

Сакните Т., Сердюк Д.О., Горемыкин В.В., Пакрастиньш Л., Ватин Н.И. Проектирование огнестойких арочных деревянных покрытий // Инженерно-строительный журнал. 2016. № 4(64). С. 26-39. 